\title{
PENGARUH KONSENTRASI DAN PANGSA PASAR TERHADAP PENGAMBILAN RESIKO BANK
}

\author{
Sesario Tri N ur Hendra \\ PT Sinar Sosro \\ Deny Dwi Hartomo \\ Fakultas Ekonomi dan Bisnis Universitas Sebelas Maret \\ email: denyhartomo@ staff.uns.ac.id
}

\begin{abstract}
This study aimed to examine the effect of concentration (Herfindahl index, concentration ratio) and market share (Market Share) torisk taking (Zscore) on go public banks in Indonesia. This study using purposive sampling method with a sample size of 40 biggest bank by assets in the country of Indonesia in 2010-2014.

These results indicate that concentration with Herfindahl index proxies positive and significant effect on risk-taking. While the concentration of the proxy Concentration ratio and market share but not significant positive effect on risk-taking.
\end{abstract}

Keywords : concentration, market share, risk taking, bank

\begin{abstract}
ABSTRAK
Penelitian ini bertujuan untuk menguji pengaruh konsentrasi (herfindahl indeks, concentration ratio) dan pangsa pasar (Market Share) terhadap pengambilan resiko (Zscore) pada perbankan go public di Indonesia. Penelitian ini menggunakan metode purposive sampling dengan jumlah sampel sebanyak 40 bank dengan asset terbesar di negara Indonesia periode 2010-2014.

Hasil penelitian ini menunjukkan bahwa konsentrasi dengan proksi Herfindahl indeks berpengaruh positif dan signifikan terhadap pengambilan resiko. Sedangkan konsentrasi dengan proksi Concentration ratio dan pangsa pasar berpengaruh positif namun tidak signifikan terhadap pengambilan resiko.
\end{abstract}

Kata kunci: konsentrasi, pangsa pasar, pengambilan resiko, bank

Dunia perbankan mempunyai peran yang sangat penting dalam pembangunan ekonomi, khususnya pada negara yang sedang berkembang seperti di Indonesia. Dari struktur sistem keuangan Indonesia, peran perbankan dalam masyarakat mendominasi dengan pangsa sekitar $80 \%$ dari total asset di sektor keuangan. Menurut undang-undang perbankan, bank memiliki fungsi intermediasi dengan kata lain merupakan badan usaha yang menghimpun dana dari masyarakat dalam bentuk simpanan dan menyalurkannya kepada masyarakat dalam bentuk kredit dan atau bentuk-bentuk lainnya dalam rangka meningkatkan taraf hidup rakyat banyak. 
Industri perbankan telah mengalami perubahan besar dalam beberapa tahun terakhir. Industri ini menjadi lebih kompetitif karena deregulasi peraturan. Saat ini, bank memiliki fleksibilitas pada layanan yang mereka tawarkan, lokasi tempat mereka beroperasi, dan tarif yang mereka bayar untuk simpanan deposan. Melihat dominasi bank terhadap pangsa pasar keuangan serta strategisnya peran bank dalam pembangunan ekonomi, maka dalam melaksanakan fungsi tersebut harus dikelelola dengan lebih hati - hati.

Namun selain memperhatikan pentinganya peran perbankan tersebut, dunia perbankan menghadapi beberapa tantangan ke depan yaitu antara lain pertumbuhan kredit yang masih lemah dan struktur perbankan yang masih belum optimal dan kokoh, karena sekitar 75\% asset perbankan nasional masih terkonsentrasi pada 11 bank besar (Abdullah, 2006). Karena belum optimalnya struktur industri perbankan di Indonesia tersebut maka perlu dilakukan penguatan struktur industri baik dari konsentrasi maupun pangsa pasar yang ada untuk mempertahankan kestabilan sistem keuangan perbankan dengan memperhatikan pengambilan resiko yang akan diambil oleh setiap bank di masa depan. Hal tersebut kemudian yang mendasari diperlukannya suatu arsitektur perbankan yang baik dan komprehensif sehingga diharapkan mampu menjadi salah satu pendukung infrastruktur kestabilan sistem keuangan secara keseluruhan.

Kemudian pada tanggal 9 Januari 2004, dikeluarkannya program Arsitektur Perbankan Indonesia yang menjadi pengaruh bahwa konsentrasi pasar yang cenderung dipegang oleh beberapa bank besar. Tujuan Arsitektur Perbankan Indonesia sebagai suatu kerangka menyeluruh arah kebijakan pengembangan industri perbankan Indonesia ke depan. Peluncuran Arsitektur Perbankan Indonesia tersebut tidak terlepas pula dari upaya Pemerintah dan Bank Indonesia untuk membangun kembali perekonomian Indonesia melalui penerbitan buku putih Pemerintah sesuai dengan Inpres No. 5 Tahun 2003, dimana Arsitektur Perbankan Indonesia menjadi salah satu program utama (BI, 2016, Arsitektur Perbankan Indonesia). Oleh karena itu, program Arsitektur Perbankan Indonesia ini mendorong bank-bank kecil dan menengah untuk melakukan akuisisi dan merger sehingga diduga berdampak terhadap munculnya gap dalam struktur pasar dan persaingan perbankan di Indonesia.

Kesenjangan ataupun gap konsentrasi struktur pasar perbankan dalam rasio konsentrasi maupun pangsa pasar yang terjadi ini jelas mempengaruhi perilaku bank yang mempunyai posisi dominan tersebut untuk mempertahankan profit yang tinggi. Sehingga fungsi intermediasi bank tidak maksimal. Sistem perbankan masih mengedepankan bunga dalam memperoleh laba perusahaan. Tingginya bunga bank merupakan perilaku yang tidak efisien yang pada akhirnya mengakibatkan sektor riil tidak dapat menjalankan peranannya dalam perekonomian karena terhambat faktor pembiayaan. Oleh karena itu, diperlukan pengetahuan tentang struktur pasar yang nantinya dapat berguna secara efisiensi bagi para pelaku ekonomi dalam setiap perencanaan serta pengambilan keputusan bisnis. Dengan mengetahui struktur pasar yang ada maka pihak bank dapat mengambil keputusan resiko yang tepat dalam menjalankan strateginya dalam memperoleh laba.

Pengambilan resiko sendiri dapat dipengaruhi oleh beberapa aspek eksternal maupun internal. Salah satu faktor eksternal yang mempengaruhi pengambilan resiko bank di Indonesia adalah persaingan antar bank ataupun konsentrasi pasar yang ada di sektor perbankan Indonesia. Berger et al. (2009) berpendapat bahwa persaingandan konsentrasi dapat saling mempengaruhiserta secara signifikan dapat berpengaruh terhadap pengambilan risiko bank.

Salah satu penelitian terdahulu telah mencoba menelaah pengambilan resiko perbankan di Indonesia, diantaranya Mulyaningsih dan Daly (2011) menjelaskan struktur pasar dan tingkat persaingan pada perbankan di Indonesia periode 2001 2009 menjadi kurang terkonsentrasi dengan adanya kebijakan konsolidasi. Dalam 
penelitian tersebut dijelaskan bahwa konsentrasi pasar perbankan di Indonesia berada pada jenis monopolistik dengan kata lain memiliki konsentrasi tinggi yang mempengaruhi pengambilan resiko bank.

Hubungan struktur, perilaku, dan kinerja berbeda-beda pada setiap industri, karena karakteristik dasar yang dimiliki berbeda. Karakteristik dasar dapat diartikan sebagai sistem yang mempengaruhi sebuah industri. Misalnya menurut Neuberger (1997), hubungan struktur-perilaku-kinerja berbeda pada industri perbankan di Amerika dan di Eropa. Hal tersebut dibuktikan dengan hubungan antara pangsa pasar, konsentrasi, dan profitabilitas. Hal ini tentu saja berbeda dalam mengukur hubungan antara struktur pasar dan kinerja dengan menggunakan paradigma Structure Conduct Performance (SCP) untuk industri lain pada umumnya dimana peningkatan konsentrasi akan meningkatkan profitabilitas perusahaan. Akan tetapi, berbeda dengan penelitian yang dilakukan oleh Mirzaei (2011) dengan judul "Does Market Structure Matter on Bank's Profitability and Stability? Emerging versus Advanced Economies" di negara berkembang dan negara maju. Penelitian ini memperoleh kesimpulan bahwa pangsa pasar tidak memiliki pengaruh yang signifikan pada profitabilitas bank di negara berkembang, tetapi memiliki pengaruh yang signifikan pada profitabilitas bank di negara maju.

Kemudian indikator konsentrasi termasuk dalam model untuk menentukan dampaknya pada stabilitas perbankan yang mempengaruhi pengambilan risiko bank. Menurut Fu et al (2014) menunjukkan pergeseran besar dalam rata-rata eksposur risiko bank yang mempengaruhi stabilitas perbankan selama periode sampel keseluruhan, disertai dengan peningkatan bertahap dalam konsentrasi.

Hubungan kompetisi dan rasio konsentrasi pasar berpengaruh signifikan dan positif terhadap pengambilan resiko yang ada. Selain itu, ada hal yang menarikuntuk menilai apakahhubungan antara persainganperbankan danpengambilan resikosaling berpengaruh setelah pecahnyakrisiskeuanganterjadi pada tahun 2013 di indonesia. Sementara itu, masih sedikit sekali literatursubstansial yang munculmenangani masalahkritis ini,khususnya penelitian mengenai hubungan ini belumcukup tercakupbagi operasi bank di seluruhregion Asia Pasifik apalagi di sektor keuangan Negara Indonesia. Maka perlu untuk dilakukan riset dengan mengkaji dan menganalisis struktur pasar yang akan berpengaruh terhadap pengambilan resiko bank dalam industri perbankan ini.

Belum banyak penelitian ataupun kajian yang meneliti tentang pengaruh struktur pasar. Termasuk perilaku didalamnya terhadap pengambilan resiko yang mempengaruhi kinerja industri perbankan terutama di negara-negara berkembang. Kemudian bagaimana hasilnya jika dibandingkan dengan yang telah dilakukan di negara-negara maju, karena di negara maju-pun masih terdapat research-gap seperti yang telah dipaparkan di atas. Oleh sebab itu pula, maka peneliti tertarik untuk menganalisis perilaku industri perbankan di Indonesia yang memiliki karakteristik yang khas dengan pendekatan organisasi industri atau industrial organization approach.

\section{TELAAH PUSTAKA}

\section{Struktur Pasar}

Stuktur pasar industri merupakan variabel yang penting untuk mempelajari ekonomi industri karena struktur pasar industri akan mempengaruhi perilaku dan kinerja perusahaan yang ada dalam industri (Naylah, 2010). Dari pernyataan diatas dapat kita ketahui bahwa struktur pasar mempengaruhi perilaku industri yang pada akhirnya akan mempengaruhi kinerja dari industri tersebut. 
Pengertian struktur pasar adalah karakteristik organisasi pasar yang mempengaruhi sifat kompetisi dan harga di dalam pasar. Adapun bentuk-bentuk Struktur pasar, meliputi :

1. Pasar Persaingan Sempurna, adalah suatu bentuk interaksi antara permintaan dengan penawaran di mana jumlah pembeli dan penjual sedemikian rupa banyaknya/tidak terbatas.

2. Pasar Persaingan Tidak Sempurna, adalah pasar yang tidak terorganisasi secara sempurna, atau bentuk pasar di mana salah satu ciri dari pasar persaingan sempurna tidak terpenuhi. Pasar persaingan tidak sempurna terdiri atas pasar monopoli, oligopoli, dan pasar persaingan monopolistik.

\section{Teori Structure Conduct Performance (SCP)}

Pada awal dipelajarinya ekonomi industri, hubungan antara struktur pasar dengan perilaku dan kinerja merupakan hubungan satu arah, namun sejalan dengan perkembangan ekonomi hubungan ketiganya semakin kompleks. Struktur pasar akan menentukan perilaku perusahaan di pasar dan perilaku perusahaan akan menentukan berbagai aspek dari kinerja perusahaan (M, Naylah. 2010)

Pendekatan SCP (Structure-Conduct-Performance) merupakan salah satu cara untuk mengukur perkiraan atau untuk menjaga perkembangan dari struktur pasar seperti kebiasaan promosi dan kinerja yang dapat merusak ketertarikan publik. Dalam SCP memperlihatkan bahwa kinerja ditentukan oleh tingkah laku perusahaan, yang ditentukan oleh karakteristik struktural dari pasar. Hubungan antara struktur, perilaku dan kinerja diturunkan ke dalam model persaingan sempurna, monopoli, monopolistik, dan oligopoly (Pertiwi, Yolanda., 2013).

Pada awal dipelajarinya ekonomi industri, hubungan antara struktur pasar dengan perilaku dan kinerja merupakan hubungan satu arah, namun sejalan dengan perkembangan ekonomi hubungan ketiganya semakin kompleks. Struktur pasar akan menentukan perilaku perusahaan di pasar dan perilaku perusahaan akan menentukan berbagai aspek dari kinerja perusahaan. Martin, (1988) menjelaskan bahwa ada hubungan langsung antara struktur pasar, perilaku perusahaan di dalam pasar, dan kinerja, meski dalam kenyataannya pengaruh tersebut tidak searah, melainkan kompleks dan interaktif.

Hubungan antara struktur, perilaku dan kinerja sekarang merupakan hubungan dua arah yang saling mempengaruhi. Ini berarti bahwa kinerja industri dapat mempengaruhi perilaku perusahaan dan perilaku perusahaan dapat mempengaruhi struktur pasar. Sebagai contohnya efisiensi dalam kegiatan usaha dan kemampuan dalam strategi perusahaan yang berubah akan mengubah peta masing-masing perusahaan, hal ini berarti berubahnya struktur pasar yang sudah ada sebelumnya. Struktur pasar, perilaku perusahaan dan kinerja dapat menentukan situasi dan kondisi pasar

\section{Franchise Value Hypothesis}

Franchise value hypothesis paling banyak mendominasi dalam berbagai literature, dimana esensi paradigm ini adalah analisis terhadap hubungan antara struktur pasar dengan perilaku pengambilan resiko yang berlebihan oleh bank (excessive risk taking) (Adriawan, T., 2012).Mekanisme ini menjelaskan bahwa franchise value memainkan peran penting dalam pengambilan resiko oleh perbankan. Franchise value mengurangi keinginan bank untuk mengambil resiko dan membuat bank relatif konservatif dalam upaya melindungi franchise value-nya sehingga akan mendorong kearah stabilitas sistem perbankan.

Namun demikian, apabila suatu ketika terjadi persaingan yang ketat yang menyebabkan turunnya profit margin bank, maka hal tersebut akan menyebabkan franchise value-nya turun. Sebagai akibatnya, bank - bank cenderung mengurangi perilaku hati - hatinya (prudence) dan mengambil langkah - langkah yang beresiko 
secara berlebihan (excessive risk taking) dalam upaya mempertahankan profit marginnya. Akibatnya bank cenderung mengalokasikan dananya kepada asset - asset dan kredit yang beresiko tinggi tetapi memberikan profit margin atau pendapatan bunga yang ting gi, sehingga berpotensi mengarah ke stabilitas sistim perbankan.

\section{Konsentrasi Pasar}

Konsentrasi dapat diartikan sebagai prosentase pangsa pasar yang dikuasai oleh perusahaan relatif terhadap pangsa pasar total. Pada prinsipnya konsentrasi tidak disebabkan karena faktor kebetulan tetapi karena adanya kekuatan permanen yang terletak di belakang konsentrasi yang biasanya tidak banyak berubah dari waktu ke waktu. Konsentrasi juga menunjukkan tingkat produksi dari pasar atau industri yang hanya terfokus pada satu atau beberapa perusahaan terbesar. Dapat pula dikatakan bahwa konsentrasi merupakan kombinasi pangsa pasar dari perusahaan-perusahaan yang terkemuka atau oligopolis, dimana perusahaan itu saling menyadari adanya saling ketergantungan satu sama Iain (Naylah, Maal., 2010). Karena alasan inilah biasanya mereka lalu bekerja sama satu sama lain membentuk organisasi terselubung untuk mempertahankan pangsa pasar yang telah dikuasai. Kelompok perusahaan oligopolis ini biasanya terdiri dari 2 hingga 8 perusahaan terbesar pada industri yang sama. Kombinasi dari pangsa pasar perusahaan-perusahaan itu nantinya membentuk suatu tingkat konsentrasi dalam pasar.

Dalam kasus persaingan sempurna, keuntungan bank akan menjadi turun, dan tidak ada potensi untuk membuat keuntungan masa depan, hal ini berkaitan dengan teori nilai franchise yang hasilnya turun pada persaingan sempurna. Bankir akan mempermudah persyaratan seleksi investasi mereka, karena mereka akan mendapat keuntungan dengan mengambil resiko dengan harapan mendapat keuntungan lebih. Sebaliknya, jika bank memiliki beberapa kekuatan pasar nilai franchise akan menjadi positif, manajer bank serta pemegang saham akan lebih bijaksana dalam mengambil risiko. Untuk mendukung paradigma nilai franchise, Allen dan Gale (2004) menggunakan model agen seperti diusulkan oleh Keeley (1990). Mereka berpendapat bahwa krisis keuangan lebih mungkin terjadi dalam sistem perbankan kurang terkonsentrasi. Ide utama di balik pandangan ini adalah bahwa kompetisi yang berlebihan mengikis nilai franchise dari bank dengan mengurangi laba mereka dan karena itu memaksa mereka untuk melakukan kegiatan yang lebih berisiko. Matutes dan Vives (2000) menyatakan bahwa kekuatan pasar yang lebih tinggi mengurangi probabilitas default bank dalam model dinamis persaingan tidak sempurna. Hellmann et al. (2000) juga menegaskan bahwa persaingan dapat mengerahkan dampak negatif pada perilaku bijaksana bank.

\section{Pangsa Pasar}

Pangsa pasar mendeskripsikan kekuatan dari setiap bank dalam pasar. Semakin tinggi nilai pangsa pasar yang dimiliki oleh bank maka kekuatan pasarnya akan semakin besar. Hal ini mengindikasikan bahwa bank tertentu mampu bersaing dalam persaingan yang terjadi. Apabila nilai pangsa pasar kecil maka dapat dikatakan bahwa bank tersebut tidak mampu bersaing dengan bank lainnya karena tidak memiliki kekuatan untuk mengendalikan pasar yang ada.

Setiap perusahaan memiliki pangsa pasarnya sendiri, dan besarnya berkisar antara 0 hingga 100 persen dari total keluaran seluruh pasar. Menurut literature NeoKlasik, landasan posisi tawar perusahaan adalah pangsa pasar yang diraihnya. Pangsa pasar dalam praktik bisnis merupakan tujuan/motivasi perusahaan. Perusahaan dengan pangsa pasar yang lebih baik akan menikmati keuntungan dari penjualan produk dan kenaikan harga sahamnya ( Naylah, Maal., 2010). Peranan pangsa pasar seperti halnya elemen struktur pasar yang lain adalah sebagai sumber keuntungan bagi perusahaan. Dengan demikian dapat diketahui bahwa pangsa pasar telah menjadi indikasi yang kuat dalam menilai kekuatan pasar. Sudah jelas bahwa apabila 
pangsa besar tinggi maka bank tersebut sangat berpengaruh terhadap pasar, begitu juga dengan sebaliknya apabila nilai pangsa pasar rendah maka kekuatan mempengaruhi pasar sangatlah rendah.

\section{Perilaku Pengambilan Resiko}

Conduct adalah perilaku perusahaan dalam menentukan harga, tingkat produksi, produk, iklan, dan perilaku terhadap pesaingnya (kolusi/kartel) menurut Greer, 1992 (Syofriza, 2002). Fokus utama dari perilaku perusahaan adalah bagaimana perusahaan bereaksi terhadap kondisi struktur pasar dan interaksi pesaingnya. Perilaku harga merupakan hal yang paling penting.

Kontrol terhadap harga menggambarkan kekuasaan perusahaan atas market power. Dimana market power adalah kemampuan perusahaan untuk mempengaruhi harga pasar dan atau mengalahkan pesaing. Perilaku akan berdampak pada strategi perusahaan, keuntungan perusahaan, hambatan untuk memasuki pasar, posisi perusahaan dalam industri, dan mempengaruhi perilaku pesaingnya.

\section{Konsentrasi Perbankan danPengambilan Resiko Bank}

Diamond(1984), RamakrishnandanThakor(1984), Boyddan Prescott(1986), Williamson(1986), dan lain-lainmenunjukkanbahwa sistemperbankan yang lebih terkonsentrasiterdiri daribankyang lebih besar dan bank yang lebih besardapatmemanfaatkanskala dan lingkupekonomidan diversifikasi lebih baik dariportofolio mereka. Karenanya, konsentrasi yang lebih besardanpersaingan kurang bisamengurangirisikokewajiban danmenyebabkanstabilitas yang lebih besardi bidang perbankan. Demikian pula, Saez dan Shi (2004) berpendapat bahwa bankbank dapat bekerja sama, bertindak secara strategis dan membantu bank-bank lain untuk mengatasi kekurangan likuiditas temporer dalam pasar ditandai dengan persaingan tidak sempurna. Allen dan Gale (2000) juga menemukan bahwa sistem perbankan yang terkonsentrasi dengan jumlah kecil dari lembaga besar adalah lebih stabil karena bank lebih mudah untuk memantau, kurang terbebani oleh pengawasan, dan karena itu lebih tahan terhadap guncangan.
Namun,
BoyddanDeNicolo
(2005)
berpendapat
bahwa

sistemperbankanterkonsentrasimemung kinkan bank untuk membebankansuku bunga pinjamanyang lebih tinggi, yang dapat mendorongpeminjamuntuk menganggap risiko yang lebih besar. Akibatnya, volumenon-performing loandapat meningkat,sehinggaprobabilitaskegagalan bank tinggi. Para penulistersebutmenyatakan bahwarisikobank mungkin tidak meningkatbahkan jikakekuatan pasarmendorongportofolioasetberisiko karena bank mungkin melindungicharter value merekadengan menggunakanmetode lainnya untukmengimbangieksposur risikoyang lebih besar. Metodetersebut dapat mencakup peningkatanmodal, mengurangirisiko suku bunga, dan menjual derivatif kredit. Sepertidisebutkan sebelumnya, pengukuranstruktur pasar mungkin bukan pengukuran yang baikdaripersaingan maupun konsentrasi dan halinitelah dikonfirmasi olehBergeretal. (2004) danBeck(2008) yangmenunjukkan konsentrasiindustri perbankan dapatmempengaruhipengambilan resiko dan berdampak pada stabilitas.

Menggunakan data dari 31 krisis perbankan sistemik di 45 negara untuk periode 1980-2005, Schaeck dkk. (2009) menunjukkan bahwa persaingan mengurangi kemungkinan krisis dan meningkatkan waktu krisis, bahkan setelah mereka mengendalikan konsentrasi sistem perbankan, yang mana berkaitan negatif dengan kerapuhan keuangan. Para peneliti jugamenemukankonsentrasiyang berhubungan negatifdenganrisiko bank, sedangkanpembatasanperaturan berpengaruh positif terhadapkerapuhanperbankan.

Secara keseluruhan, beragam bukti penelitian diatas menghasilkanhasil yang beragammengenai hubungan antarakompetisi perbankandan stabilitas 
keuangan.Sementara itu,temuanmelakukan konfirmasi bahwakonsentrasi dapat mempengaruhipengambilan resiko melalui saluran yang berbeda. Berdasarkan hal tersebut, maka hipotesis yang dirumuskan sebagai berikut:

\section{H1 : Konsentrasi perbankan berpengaruh negatif terhadap pengambilan resiko bank yang ada di Indonesia.}

\section{Pangsa Pasar Bankdan Pengambilan Resiko Bank}

Mirzaei (2011) meneliti tentang pengaruh struktur pasar terhadap kinerja dan stabilitas bank antara negara berkembang dengan negara maju. Studi dilakukan di negara-negara Eropa, yang menyimpulkan bahwa struktur pasar tidak memiliki dampak signifikan terhadap pengambilan resiko dan profitabilitas bank di negara berkembang tetapi sebaliknya di negara maju. Konsentrasi pasar juga memiliki efek negatif terhadap pengambilan resiko dan profitabilitas bank di negara berkembang, spread bunga yang lebih tinggi meningkatkan profitabilitas dan stabilitas di kedua negara.

Perbedaan hasil penelitian juga terjadi pada penelitian Naylah (2010) dengan penelitiannya berjudul Pengaruh Struktur Pasar Terhadap Kinerja Industri perbankan Indonesia. Studi empiris ini menemukan bahwa industri perbankan Indonesia mendukung hipotesis tradisional. Kemudian dijelaskan juga bahwa konsentrasi pasar mempengaruhi profitabilitas pada industri perbankan Indonesia, yang artinya bahwa pengambilan resiko juga dipengaruhi oleh struktur pasar berupa konsentrasi dan pangsa pasar.

Berdasarkan beragam penelitian diatas menghasilkanhasil yang beragammengenai hubungan antarakonsentrasiperbankandan stabilitas. Sedangkan,temuanmelakukan konfirmasi bahwapangsa pasardapat mempengaruhipengambilan resiko melalui saluran yang berbeda pula. Berdasarkan hal tersebut, maka dapat dirumuskan hipotesis sebagai berikut:

\section{H2 : Pangsa pasar bank berpengaruh negatif terhadap pengambilan resiko bank yang ada di Indonesia.}

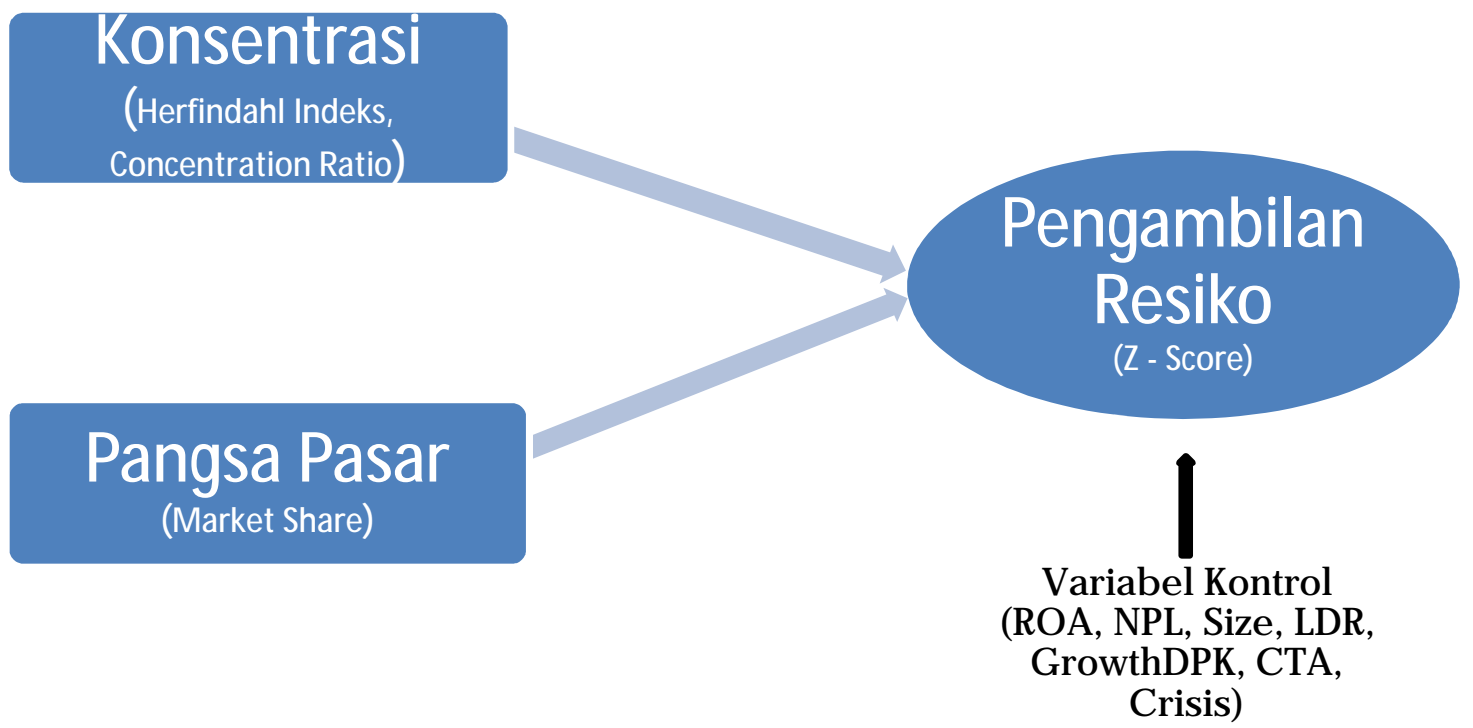

Gambar 1. Kerangka Penelitian 


\section{METODE PENELITIAN}

\section{Data / Objek Penelitian, Sample dan Sampling}

Dalam penelitian ini data yang digunakan adalah Lembaga Bank Umum di Indonesia. Pada penelitian ini populasi menggunakan 120 bank umum di Indonesia. Penelitian ini mengambil sampel 40 bank umum di Indonesia yang memiliki aset terbesar, ini dikarenakan 40 bank umum tersebut menguasai pangsa lebih dari $75 \%$ total pangsa pasar bank umum yang ada, sehingga dianggap sampel tersebut dapat mewakili industri perbankan dengan baik. Kemudian dengan kurun waktu pengamatan sejak tahun 2010 sampai dengan tahun 2014. Adapun kriteria sampel yang digunakan sebagai berikut:

1. Bank yang diamati pada tahun 2010 - 2014.

2. Bank yang mempublikasikan laporan keuangan mereka pada tahun penelitian.

3. Bank tersebut memberikan data informasi tahunan neraca danlaporan laba rugi mereka, serta mewakili pangsa basar lebih dari $75 \%$ dari total asset

4. Bank yang mewakili keseluruhan jenis bank yaitu bank asing, bank pemerintah, serta bank swasta

5. Bank tersebut menampilkan informasi yang lengkap mengenai proxy variabel dependen dan independen yaitu pengambilan resiko, konsentrasi, maupun market share dalam laporan keuangan pada tahun penelitian.

\section{Definisi Operasional dan Pengukuran Variabel}

\section{Variabel Independen}

Variabel independen pada penelitian ini yaitu rasio konsentrasi pendapatan dan pangsa pasar dana pihak ketiga yang diukur dengan menggunakan proxy indeks Herfindahl-Hirschman, Concentration Ratio, serta Market Share Ratio.

Indeks Herfindahl adalah ukuran konsentrasi produksi dalam industri yang dihitung sebagai jumlah kuadrat dari pangsa pasar masing-masing perusahaan. Indeks ini dapat mengukur seberapa oligopolistik suatu industri dan seberapa besar konsentrasi kekuatan pasar yang dimiliki oleh perusahaan-perusahaan terbesar di industry (Kamus Bisnis, 2015 )

$$
\mathbf{H H I}=\sum_{i=1}^{n}\left(\frac{\text { Total Pendapatan Jasa Bank }}{\text { Total pendapatan jasa dalam industri }}\right)^{2}
$$

Keterangan :

$\mathrm{HHI}=$ Indeks Herfindahl - Hirschman

Interprestasi angka HHI adalah dengan menggunakan Kriteria dari Komisi Pengawasan Persaingan Usaha sebagai berikut :

Nilai HHI $<0.18=$ Tingkat Konsentrasi Rendah (Spektrum I)

Nilai HHI $>0.18=$ Tingkat Konsentrasi Tinggi (Spektrum II)

Kemudian, proxy lain dalam mengukur konsentrasi pasar jumlah pendapatan 3 bank terbesar dapat diketahui dengan menggunakan Concentration Ratio, yaitu :

$\mathbf{C R 3}=\sum_{i=1}^{3} \frac{\text { Total Asset Jasa Bank }}{\text { Total Asset dalam industri }}$

Keterangan :

CR3 = Concentration Ratio tiga bank terbesar berdasarkan pendapatan

Hasil dari CR3 berupa ukuran dengan satuan persen (\%). 
Sedangkan, proxy untuk menghitung pangsa pasar dana pihak ketiga dapat diketahui dengan menggunakan ratio market share, yaitu :

$$
M S=\frac{\text { total DPK bank umum } i}{\text { total Dana Pihak Ketiga seluruh bank umum }}
$$

Market Share atau pangsa pasar dihitung dengan memperhitungkan total dana pihak ketiga yang dimiliki oleh sebuah bank relatif terhadap total dana pihak ketiga bank umum dalam industri perbankan dengan satuan persen (\%).

\section{Variabel Dependen}

Variabel dependen dalam penelitian ini adalah pengambilan resiko bank umum yang diproksi dengan indeks Z - Score.

$$
\begin{aligned}
& \mathbf{Z}_{\mathbf{i t}}=\frac{R O A_{i t}+\left(\frac{E}{T A}\right)_{i t}}{\sigma(R O A)_{i t}} \\
& \text { Keterangan : } \\
& Z_{\text {it }}=\text { Z-Score } \\
& \text { ROA }=\text { Return on assets (net income / total asset) } \\
& \text { E/TA = rasio ekuitas terhadap total asset } \\
& \sigma_{\text {ROA }}=\text { Standard Deviasi dari return on assets }
\end{aligned}
$$

\section{Variabel Kontrol}

Return On Asset yaitu rasio laba bersih setelah pajak terhadap total asset. Non performing loan yang diukur sebagai rasio kredit macet terhadap total kredit, dan Ukuran Bankyang diwakili oleh logaritma dari total aset bank. Kemudian juga proxy Loan to Deposit Ratio yang diukur menggunakan rasio total pinjaman terhadap total dana pihak ketiga. Selanjutnya Growth dana pihak ketiga yang diukur menggunakan rasio deposit tahun tertentu terhadap tahun sebelumnya. Dan yang terakhir yaitu Capital to Total Asset yang merepresentasikan likuiditas bank diukur menggunakan rasio equity terhadap total asset, serta crisis yang diukur menggunakan variabel dummy.

Adapun pengukurannya menggunakan :

$$
\begin{aligned}
\text { ROA } & =\frac{\text { Laba Bersih setelah Pajak }}{\text { Total Asset }} \\
\text { NPL } & =\frac{\text { Total } \text { Kredit Macet }}{\text { Totasl Kredit }} \\
\text { LDR } & =\frac{\text { Total Kredit }}{\text { Total Deposit }} \\
\text { Size } & =\ln \text { (Total asset) }
\end{aligned}
$$

$$
\begin{aligned}
& \text { Growth }=\frac{\text { DPKt }- \text { DPK }(\mathrm{t}-1)}{\text { DPK }(\mathrm{t}-1)} \\
& \text { CTA }=\frac{\text { Ekuitas }}{\text { Total Asset }} \\
& \text { Crisis = Dummy variabel untuk tahun } \\
& \text { crisis pada waktu tertentu }
\end{aligned}
$$

\section{HASI L PENELITIAN DAN PEMBAHASAN}

\section{Gambaran Umum Objek Penelitian}

Objek dari penelitian ini merupakan seluruh bank yang mewakili 75\% asset industri perbankan yang terdaftar di bank Indonesia, selama 5 tahun yaitu mulai dari tahun 2010 sampai dengan tahun 2014. Setelah melalui tahap penyeleksian sesuai dengan persyaratan beberapa kriteria bank seperti yang telah dijelaskan dalam bab sebelumnya maka diperoleh sampel 40 bank dengan jumlah observasi sebanyak 200.

Analisis data yang digunakan ialah regresi berganda dengan menggunakan metode panel data yang menggabungkan antara data cross section dengan data time series. Setelah melakukan Chow Test serta Hausman Test dapat diperoleh metode yang sesuai yaituFixed Effect Method karena dapat menjelaskan dinamisasi antar individu. 
Bank yang diteliti dalam penelitian ini mewakili seluruh jenis bank yang ada, yaitu bank asing, bank pemerintah, serta bank swasta. Adapun dalam penelitian ini memperhatikan dampak krisis keuangan yang terjadi pada tahun 2013 kemarin. Kemudian dari sampel yang telah diperoleh akan dilakukan uji hipotesis apakah terdapat hubungan yang signifikan antara pengaruh struktur pasar berupa konsentrasi dan pangsa pasar terhadap pengambilan resiko bank yang nantinya akan berdampak terhadap kinerja perusahaan.

\section{Tabel 1. Hasil Chow Test}

Redundant Fixed Effects Tests

Test cross-section fixed effects

\begin{tabular}{crrr}
\hline \hline Effects Test & Statistic & d.f. & Prob. \\
\hline \hline Cross-section F & 3.773385 & $(39,150)$ & 0.0000 \\
Cross-section Chi-square & 136.728449 & 39 & 0.0000 \\
\hline \hline
\end{tabular}

Dari hasil Tabel 1 dapat diketahui bahwa $\mathrm{H}_{0}$ ditolak karena P-value lebih kecil dari nilai a. Nilai a yang digunakan sebesar $5 \%$. Sehingga dapat disimpulkan bahwa Metode Fixed Effect lebih baik.

Tabel 2. Hasil Hausman Test

Correlated Random Effects - Hausman Test

Test cross-section random effects

\begin{tabular}{cccc}
\hline \hline Test Summary & $\begin{array}{l}\text { Chi-Sq. } \\
\text { Statistic C Chi-Sq. d.f. }\end{array}$ & Prob. \\
\hline \hline Cross-section random & 0.000000 & 10 & 1.0000 \\
\hline \hline * C ross-section test variance is invalid. Hausman statistic set to \\
zero.
\end{tabular}

Kemudian, dari Tabel 2 dapat diketahui bahwa Hausman test yang telah dilakukan tidak valid, hal ini dikarenakan salah satu variabel independen dari data penelitian tidak memenuhi syarat adanya random effect. Sedangkan apabila dalam data penelitian tidak memenuhi syarat adanya random effect maka program eviews akan menolak adanya Hausman test. Sehingga dapat disimpulkan bahwa jelas Metode Fixed Effect lebih baik.

Statistika Deskriptif

Tabel 3. Hasil Statistik Deskriptif

\begin{tabular}{|c|c|c|c|c|c|c|c|c|c|c|c|}
\hline Statistic & score & $\mathrm{HI}$ & $C R$ & MS & ROA & NPL & Crisis & Growth & Cta & LDR & Size \\
\hline Mean & & & & & & & & & & & \\
\hline & & & & & & & & & & & \\
\hline & & & & & & & & & & & \\
\hline & 0 & & & & 0,00 & & & & & & \\
\hline & 0,9122 & 0,0083 & 0,0087 & & 0,0081 & & & & & & 1,0629 \\
\hline & & & 4,00 & & & & & & & & 18,86 \\
\hline Probability & 0,0000 & 0,0000 & 0,1352 & 0,0000 & 0,0229 & 0,0000 & 0,0000 & 0,0000 & 0,0066 & 0,0000 & 0,0000 \\
\hline
\end{tabular}




\section{Uji Normalitas}

Dengan nilai chi square $\left(x^{2}\right)$ tabel $(\mathrm{df}=11)=19.675$ maka dapat diketahui dimana nilai JB hitung <chi square $\left(x^{2}\right)$ tabel : yang artinya menyatakan bahwa nilai residual adalah terdistribusi normal dan $H_{0}$ diterima. Sehingga jelas dapat disimpulkan, setelah melalui uji normalitas, model regresi yang diteliti residualnya terdistribusi secara normal.

\section{Uji Multikolinieritas}

Dari Uji multikolinieritas diharapkan dalam model regresi tidak terdapat korelasi antar variabel bebas. Oleh karena itu model regresi yang baik seharusnya tidak terdapat korelasi di antara variabel independen. Dari uji yang telah dilakukan diatas diketahui bahwa hasil korelasi antar variabel independen tidak ada yang bernilai 1 walaupun salah satu variabel dengan variabel lainnya ada yang berkorelasi tinggi dengan derajat korelasi lebih dari 0,8 yaitu antara Size dengan Market Share dengan nilai sebesar 0,83. Hal ini terjadi karena proksi Market Share dihitung dengan menggunakan total Dana Pihak Ketiga, yang mana merupakan bagian dari Total Asset sebagai proksi dari Size. Namun secara keseluruhan tidak terdapat derajat kolerasi yang bernilai 1 sehingga dapat disimpulkan bahwa penelitian ini bebas dari adanya masalah multikolinieritas.

\section{Uji Heteroskedastisitas}

Dari hasil olah data dapat dijelaskan bahwa hampir semua nilai p-value keseluruhan variabel independen bersifat tidak signifikan walupun masih ada satu variabel yang signifikan, maka dengan demikian dapat disimpulkan bahwa tidak ada masalah heteroskedastisitas pada model. Sehingga dapat menerima $\mathrm{H}_{0}$ bahwa data bersifat homoskedastik.

\section{Uji Autokorelasi}

Dengan taraf keyakinan 95 persen $(\alpha=0,05)$ diperoleh nilai $\mathrm{dl}=1,66$ dan nilai $\mathrm{du}$ $=1,87$. Berdasarkan hasil perhitungan, diperoleh nilai Durbin Watson (DW) sebesar 2,23 yang kemudian dengan mengacu pada grafik pengambilan keputusan statistik Durbin Watson maka hasil pengujiannya menunjukkan bahwa nilai DW 2,23 tersebut berada pada daerah keragu-raguan yang artinya model penelitian belum dapat dipastikan terdapat autokorelasi negatif atau tidak, akan tetapi ada kemungkinan bebas dari masalah autokorelasi.

\section{Analisis Regresi}

Tabel 4. Hasil Analisis Regresi

\begin{tabular}{crrrl}
\hline \hline Variable & Coefficient & Std. Error & t-Statistic & Prob. \\
\hline \hline HI & 19.63842 & 9.616130 & 2.042237 & $0.0429 * *$ \\
CR & 4.266355 & 10.52863 & 0.405215 & 0.6859 \\
MS & 29.38873 & 19.14546 & 1.535024 & 0.1269 \\
ROA & 23.97577 & 10.54328 & 2.274034 & $0.0244 * *$ \\
NPL & -0.380259 & 0.073547 & -5.170290 & $0.0000 * * *$ \\
CRISIS & 0.596780 & 0.134294 & 4.443842 & $0.0000 * * *$ \\
G ROWTH & -0.732555 & 0.220405 & -3.323679 & $0.0011 * * *$ \\
CTA & 3.926873 & 2.671189 & 1.470084 & 0.1436 \\
LDR & -0.263512 & 0.341781 & -0.770996 & 0.4419 \\
SIZE & -0.235242 & 0.430452 & -0.546501 & 0.5855 \\
C & 2.595388 & 11.88300 & 0.218412 & 0.8274 \\
\hline \hline
\end{tabular}




$\begin{array}{cccc}\text { R-squared } & 0.733854 & \text { Mean dependent var } & 5.208062 \\ \text { Adjusted R-squared } & 0.646913 & \text { S.D. dependent var } & 2.530361 \\ \text { S.E. of regression } & 0.630067 & \text { Sum squared resid } & 59.54758 \\ \text { F-statistic } & 8.440823 & \text { Durbin-Watson stat } & 2.236048 \\ \text { Prob(F-statistic) } & 0.000000 & & \end{array}$

* signifikan pada level $10 \%$

** signifikan pada level $5 \%$

*** signifikan pada level $1 \%$

sumber: data yang diolah (2016)

\section{Herfindahl Indeks terhadap Zscore}

Hasil dari model regresi data panel menjelaskan bahwa konsentrasi pasar yang diproksikan dengan herfindahl indeks (HI) mempunyai pengaruh positif dan signifikan terhadap pengambilan resiko (Zscore). Hal ini berarti semakin tinggi nilai herfindahl indeks (HI) dapat diartikan bahwa konsentrasi pasar dalam suatu industri semakin terkonsentrasi dan akan menyebabkan tingkat persaingan menurun sehingga akan mempengaruhi pengambilan resiko (Zscore) yang semakin tinggi. Hasil analisis regresi pada model regresi data panel mendukung hipotesis yang diteliti pada penelitian ini.

Hasil dari penelitian ini sesuai dengan penelitian yang dilakukan oleh Mulyaningsih dan Daly (2011), Fu et al (2014), Diamond(1984), RamakrishnandanThakor(1984), Boyddan Prescott(1986), Williamson(1986), Bergeretal. (2004) danBeck(2008) namun memiliki arah yang berdeda, yang semuanya mengemukakan hasil yang hampir sama bahwa pasar yang lebih terkonsentrasi akan mengakibatkan persaingan kurangyang kemudian dapatmengurangirisikokewajiban sehingga pengambilan resiko akan semakin berkurang pula akibatnya dapatmenyebabkanstabilitas di bidang perbankan menurun.

\section{Concentration Ratio terhadap Zscore}

Model regresi data panel penelitian ini menjelaskan bahwa Concentration Ratio (CR) yang dikontrol dengan variabel return on asset (ROA), non-performing loan (NPL), waktu krisis (Crisis), pertumbuhan DPK (Growth), kecukupan modal (CTA), likuiditas (LDR), dan ukuran perusahaan (SIZE) memiliki pengaruh yang tidak signifikan terhadap pengambilan resiko (Zscore). Berarti dapat dikatakan bahwa semakin ting gi Concentration Ratio maka pasar suatu industri semakin terkonsentrasi, diduga menyebabkan kompetisi antar bank semakin menurun karena pasar dikuasai bank bank besar. Akibatnya semakin tinggi pengambilan resiko yang ada.

Hal ini memiliki arah yang berbeda seperti teori Franchise value yang menyatakan bahwa semakin rendah nilai CR menyebabkan turunnya profit margin bank, maka hal tersebut akan menyebabkan franchise value-nya turun. Sebagai akibatnya, bank - bank cenderung mengurangi perilaku hati - hatinya (prudence) dan mengambil langkah - langkah yang beresiko secara berlebihan (excessive risk taking) dalam upaya mempertahankan profit margin-nya. Akibatnya bank cenderung mengalokasikan dananya kepada asset - asset dan kredit yang beresiko tinggi tetapi memberikan profit margin atau pendapatan bunga yang tinggi, sehingga berpotensi mengarah ke stabilitas sistim perbankan.

Hasil dari penelitian ini sesuai dengan penelitian yang dilakukan oleh Mirzaei (2011) namun dengan arah yang berbeda, yang menyimpulkan bahwa struktur pasar tidak memiliki dampak signifikan terhadap pengambilan resiko dan profitabilitas bank di negara berkembang. Konsentrasi pasar juga memiliki efek negatif terhadap pengambilan resiko dan profitabilitas bank di negara berkembang, spread bunga yang lebih tinggi meningkatkan pengambilan resiko dan profitabilitas. 


\section{Market Share terhadap Zscore}

Hasil analisis regresi data panel menunjukkan bahwa pangsa pasar (MS) memiliki pengaruh yang tidak signifikan. Hal ini dapat dikatakan bahwa semakin tinggi nilai pangsa pasar (MS) yang dimiliki suatu bank berarti semakin tinggi kekuatan pasar yang dimiliki suatu bank dan akan membuat persaingan antar bank semakin turun sehingga bank tersebut menjadi semakin banyak melakukan proses pengambilan resiko (Zscore) yang akan diambil karena pihak bank akan mendapat keuntungan yang diinginkan.

Hasil penelitian tersebut sesuai dengan penelitian yang dilakukan oleh Matutes dan Vives (2000) namun dengan arah yang berbeda, menyatakan bahwa kekuatan pasar yang lebih tinggi mengurangi pengambilan resiko bank dalam model dinamis persaingan tidak sempurna. Hellmann et al. (2000) juga menegaskan bahwa rendahnya pangsa pasar yang menciptakan persaingan dapat mengerahkan dampak negatif pada perilaku bijaksana bank yang mana lebih banyak melakukan pengambilan resiko.

\section{SIM PULAN}

\section{Simpulan}

1. Herfindahl Indeks (HI) mempunyai pengaruh yang signifikan terhadap Risk - taking (Zscore). Berarti semakin rendah nilai Herfindahl Indeks akan mempengaruhi pengambilan resiko (Zscore) yang semakin tinggi. Hal ini memiliki arah yang berdeda dengan peneitian sebelumnya, yang mengemukakan bahwa pasar yang lebih terkonsentrasi akan mengakibatkan persaingan kurangyang kemudian dapatmengurangipengambilan resiko.

2. Concentration Ratio (CR) berpengaruh tidak signifikan terhadap Risk - taking (Zscore). Dapat diketahui bahwa semakin tinggi CR akan mempengaruhi pengambilan resiko (Zscore) yang semakin tinggi pula. Hal ini juga memiliki arah yang berbeda dengan penelitian sebelumnya, yang menyatakan bahwa struktur pasar tidak memiliki dampak signifikan terhadap pengambilan resiko dan profitabilitas bank di negara berkembang. Konsentrasi pasar memiliki efek negatif kemudian spread bunga yang lebih tinggi meningkatkanpengambilan resiko dan profitabilitas sehing ga menuju stabilitas perbankan.

3. Market Share (MS) berpengaruh tidak signifikan terhadap Risk - taking (Zscore). Hal ini berarti bahwa semakin tinggi Market Share (MS) maka akan semakin tinggi pula nilai pengambilan resiko (ZScore). Hal tersebut memiliki arah yang berbeda pula dengan penelitian sebelumnya yang menjelaskan bahwa kekuatan pasar yang lebih tinggi mengurangi pengambilan resiko bank dalam model dinamis persaingan tidak sempurna.

\section{Implikasi}

1. Dalam melakukan pengambilan resiko bank harus memperhatikan konsentrasi pasar ketika terdapat krisis keuangan pada waktu tertentu. Selain itu sebelum pelakukan pengambilan resiko bank harus mengelola Return On Asset menjadi lebih meningkat, Non - Performing Loan lebih sedikit serta pertumbuhan Dana Pihak Ketiga lebih banyak agar mendapatkan profit margin yang diinginkan.

2. Dalam melakukan investasi pada dunia perbankan, pihak investor harus memperhatikan kondisi kecukupan modal yang tinggi, likuiditas tinggi, serta ukuran perusahaan yang lebih besar dengan bank yang akan diajak kerjasama sehingga mendapatkan keuntungan yang diharapkan. 


\section{Keterbatasan}

1. Jenis data yang diambil dari penelitian ini berupa data panel, yang mana merupakan gabungan data cross - section dan time series. Sehingga sangat dimungkinkan timbul nilai residual dari model yang tidak memiliki varians yang konstan. Artinya, setiap observasi mempunyai reliabilitas yang berbeda-beda akibat perubahan kondisi yang melatarbelakangi antar bank. Oleh karena itu, sangat dimungkinkan pada data panel terdapat heteroskedastisitas maupun autokorelasi.

2. Tidak konsistennya sebuah bank dalam mempublikasikan laporan keuangan yang menyebabkan kurangnya informasi yang valid mengenai data yang diperlukan dalam penelitian ini menjadi kesulitan bagi penelitian melakukan pengumpulan data.

3. Variabel kontrol yang digunakan dalam penelitian ini hanya menggunakan rasio profitablitas yang diukur dengan ROA, waktu krisis yang diukur dengan Crisis, pertumbuhan DPK yang diukur dengan GrowthDPK, rasio kecukupan modal yang diukur dengan proksi CTA, likuiditas yang diukur dengan LDR, serta ukuran bank yang dihitung dengan Log Natural dari Total Asset.

\section{Saran}

1. Bagi Bank

Bagi dunia perbankan, suatu bank dalam mengambil keputusan resiko setidaknya harus memperhatikan faktor struktur pasar seperti konsentrasi dan pangsa pasar mereka masing - masing. Sehingga dapat memperoleh profit margin yang paling optimal dari kondisi keuangan yang mereka miliki. Karena tidak dapat dipungkiri, berdasarkan teori hipothesis Structure Conduct Performance (SCP) yang menjelaskan bahwa konsentrasi dan pangsa pasar akan mempengaruhi persaingan bank yang menyebabkan perilaku proses pengembilan resiko yang berbeda beda sesuai kondisi mereka masing - masing untuk mendapatkan profitabilitas yang paling optimal yang bisa mereka dapatkan.

2. Bagi Investor

Sudah seharusnya para investor memperhatikan kondisi struktur pasar suatu industri dalam hal ini dunia perbankan. Sehingga dapat mengalokasikan dananya kepada tempat yang sesuai. Selain itu juga diperlukan perhatian terhadap kondisi pasar industri perbankan apakah terjadi krisis keuangan ataukah tidak dan dapat meminimalisir kerugian serta dapat menerima profitiabilitas yang diinginkan.

Kemudian sudah selayaknya para investor juga memperhatikan tata kelola maupun kondisi keuangan perusahaan yang akan diajak bekerjasama seperti rasio profitabilitas, likuiditas, kecukupan modal, tingkat kredit macet, ukuran perusahaan dan lain - lain sehingga dapat menyesuaikannya dengan kemampuan dana masingmasing investor.

3. Bagi Penelitian Selanjutnya

Diharapkan bagi peneliti selanjutnya yang akan meneliti dengan kajian yang hampir sama dapat memberikan variabel tambahan yang berkaitan dengan konsentrasi pasar terhadap pengambilan resiko. Hal tersebut misalnya seperti variabel kompetisi yang mana sudah dijelaskan bahwa variabel kompetisi dapat hidup berdampingan dengan variabel konsentrasi bersama-sama mempengaruhi pengambilan resiko yang nantinya mempengaruhi stabilitas perbankan yang ada. Hal tersebut sangat menarik untuk diteliti karena hubungan konsentrasi dan kompetisi terhadap pengambilan resiko sendiri sangatlah penting bagi dunia perbankan khususnya pada waktu krisis keuangan yang baru-baru ini terjadi. 


\section{DAFTAR PUSTAKA}

Abdullah, Burhanuddin. 2006. Jalan menuju Stabilitas : Mencapai Pembangunan Ekonomi Berkelanjutan. LP3ES, Jakarta.

Adriawan, T., 2012. Analisis Dampak Penerapan dan Kebijakan Aristektur Perbankan Indonesia (API) terhadap Struktur Persaingan dan Stabilitas Bank Umum DI Indonesia. Universitas Indonesia.

Allen, F., Gale, D., 2000. Financial contagion. Journal of Political Economy108, 1-33.

Allen, F., Gale, D., 2004. Competition and financial stability. Journal Money Credit Bank. $36,453-480$.

Bank Indonesia, 2016. Arsitektur Perbankan Indonesia (http://www.bi.go.id/). Diakses 16 Februari 2016.

Beck, T., 2008. Bank Competition and Financial Stability: Friends or Foes? Policy Research W orking Paper No. 4656, World Bank.

Berger, A., Demirguc-Kunt, A., Levine, R., Haubrich, J., 2004. Bank concentration and competition: an evolution in the making. Journal of Money, Credit and Banking 36, 433-453.

Berger, A., Klapper, L., Turk-Ariss, R., 2009. Bank competition and financial stability. Journal of Financial ServicesResearch 35, 99-118.

Boyd, J.H., De Nicolo, G., 2005. The theory of bank risk-taking and competition revisited. Journal of Finance 60, 1329-1343.

Boyd, J.H., Prescott, E.C., 1986. Financial intermediary-coalitions. Journal of Economic Theory 38, 211-232.

Diamond, D., 1984. Financial intermediation and delegated monitoring. Review of Economic Studies 51, 393-414.

Fu, X.M., Lin, Y.R., Molyneux, P., 2014. Bank competition and financial stability in Asia Pacific. Journal Bank Finance. 38, 64-77.

Hellmann, T.F., Murdock, K., Stiglitz, J., 2000. Liberalization, moral hazard in banking and prudential regulation: are capital requirements enough? American Economic Review. 90, 147-165.

Keeley, M., 1990. Deposit insurance, risk, and market power in banking. American Economic Review 80, 1183-1200.

Mirzaei, Ali., Liu, Guy., Moore, Tomoe., 2011. Does Market Structure Matter on Bank's Profitability and Stability? Emerging versus Advanced Economies. Brunel University.

Matutes, C., Vives, X., 2000. Imperfect competition, risk-taking and regulation in banking. European Economic. Rev. 44, 1-34.

Mulyaningsih, Tri, and Daly, Anne. 2011. Competitive Conditions in Banking Industry : An Empirical Analysis of The Consolidation, Competition and Concentration in the Indonesia Banking Industry between 2001 and 2009. University of Canberra.

Martin, Stephen. 1988. Industrial Economic - Economic Analysis and Public Policy. Second Edition, Macmillan Publishing Company. New York.

Naylah, Maal., 2010. Pengaruh Struktur pasar Terhadap Kinerja Industri Perbankan di Indonesia.Tesis Program Pasca Sarjana, Universitas Diponegoro.

Neuberger, Doris, 1997, Structure, Conduct, and Performance in Banking Markets.W orking Paper no.12. Universitat Rostock.

Pertiwi, Yolanda., 2013. Pengaruh Struktur Pasar Industri Perbankan dan Karakteristik Bank terhadap Profitabilitas Bank Konvensional di Indonesia Periode 2006 2011. Tesis.Universitas Diponegoro.

Ramakrishnan, R., Thakor, A., 1984. Information reliability and a theory of financial intermediation. Review of Economic Studies 51, 415-432. 
Saez, L., Shi, X., 2004. Liquidity pools, risk sharing and financial contagion. Journal of Financial Services Research 25, 5-23.

Schaeck, K., Cihak, M.,Wolfe, S., 2009. Are more competitive banking systems more stable? Journal Money Credit Bank. 41, 567-807.

Williamson, S., 1986. Costly monitoring financial intermediation, and equilibrium credit rationing. Journal of Monetary Economics 18, 159-179. 